University of Rhode Island

DigitalCommons@URI

Civil \& Environmental Engineering Faculty

Publications

Civil \& Environmental Engineering

2014

\title{
Effect of Local Materials on the Silver Sorption and Strength of Ceramic Water Filters
}

Vinka Oyanedel-Craver

University of Rhode Island, craver@uri.edu

Sophia Narkiewicz

Richard Genovesi

Aaron Bradshaw

University of Rhode Island, abrads@uri.edu

Dawn Cardace

University of Rhode.Island, cardace@uri.edu Follow this and additional'works at: $\mathrm{nttps}$ ://digitalcommons.uri.edu/cve_facpubs

The University of Rhode Island Faculty have made this article openly available.

Please let us know how Open Access to this research benefits you.

This is a pre-publication author manuscript of the final, published article.

Terms of Use

This article is made available under the terms and conditions applicable towards Open Access

Policy Articles, as set forth in our Terms of Use.

\section{Citation/Publisher Attribution}

Vinka, O.C, Narkiewicz, S., Genovesi, R., Bradshaw, A., \& Cardace, D. (2014). Effect of Local Materials on the Silver Sorption and Strength of Ceramic Water Filters. Journal of Environmental Chemical Engineering, 2(2), 841-848. doi: 10.1016/j.jece.2014.02.002

Available at: http://www.dx.doi.org/10.1016/j.jece.2014.02.002

This Article is brought to you for free and open access by the Civil \& Environmental Engineering at DigitalCommons@URI. It has been accepted for inclusion in Civil \& Environmental Engineering Faculty Publications by an authorized administrator of DigitalCommons@URI. For more information, please contact digitalcommonsgroup@uri.edu. 


\section{EFFECT OF LOCAL MATERIALS ON THE SILVER SORPTION AND STRENGTH OF CERAMIC WATER FILTERS}

Vinka Oyanedel-Craver ${ }^{1}$, Sophia Narkiewicz ${ }^{1}$, Richard Genovesi ${ }^{1}$, Aaron Bradshaw ${ }^{1}$, and Dawn Cardace $^{2}$,

${ }^{1}$ Department of Civil and Environmental Engineering, University of Rhode Island, Kingston, RI.

${ }^{2}$ Department of Geosciences, University of Rhode Island, Kingston, RI.

*Corresponding author

\section{ABSTRACT}

In this paper, we present a systematic evaluation of the effects of local clays and the manufacturing process on the performance of ceramic water filters (CWFs) impregnated with silver compounds, which are used for point-of-use water treatment in developing countries. Mineral composition, silver sorption/desorption, and strength are the important characteristics that influence effectiveness and durability of CWFs during transport and use. Laboratory tests were conducted on ceramic samples obtained from five CWF factories around the world to determine their mineral composition, silver sorption/desorption, and flexural strength. The results of this study showed that clays that contain traces of crystalline albite or crystalline pyroxene have better sorption of silver species than those that do not. The results showed that the Freundlich model provided the best fit for both ionic silver and silver nanoparticles for all of the ceramic materials that were tested. Thus, this model can be used to optimize the manufacturing process and the application of silver. Silver nanoparticles were desorbed more slowly than ionic silver, so they last longer in the ceramic material. Water that contains a high concentration of divalent ions is not recommended for preparing solutions of silver nanoparticles due to aggregation of the particles, which limits their sorption by the ceramic materials. In this study, the mineralogy of the source materials was found to have the most significant influence on the strength of ceramic filters. 
Keywords: mineral composition, silver, sorption, desorption, flexural strength

\section{INTRODUCTION}

Ceramic water filters (CWFs) impregnated with silver nanoparticles were developed in Guatemala by Dr. Fernando Mazariegos with the support of the World Bank and the InterAmerican Bank. Dr. Mazariegos' work involved the evaluation of ten models of low-cost, domestic water filters. In response to Hurricane Mitch in 1999, Potters for Peace used CWFs as a sustainable water treatment technology in Nicaragua [1]. At present, there are more than 30 established ceramic filter manufacturing facilities in 20 countries that produce about 40,000 filters per month [1]. These silver-impregnated CWFs are easy to use, requiring little training for the users, and they are produced locally and require no additional chemicals for operation.

Ceramic filters are manufactured by pressing and firing a mixture of clay and a combustible material, such as flour, rice husks, or sawdust, prior to treatment with silver nanoparticles. The filters are formed using a filter press, after which they are air-dried and fired in a flat-top kiln, in which the temperature in increased gradually to about $900{ }^{\circ} \mathrm{C}$ over an eighthour period. This forms the ceramic material and combusts the sawdust, flour, or rice husks in the filters, making it porous and permeable to water [1]. After firing, the filters are cooled and impregnated with a silver solution (either silver nanoparticles or silver nitrate) by painting it onto the filters or dipping the filters in a bath of the solution. It has been demonstrated that the silver solution adds disinfectant properties to the $\mathrm{CWF}$, thereby decreasing the bacteria concentration and increasing the quality of the water.

Ionic silver and silver nanoparticles are used extensively for their medicinal and disinfectant properties [2-7]. It has been demonstrated that silver ions produce reactive oxygen species (ROS) by proxy [8], prevent the replication of DNA, and affect the permeability and 
52 structure of the cell membrane [9]. Similarly, silver nanoparticles have different anti-microbial

53 mechanisms, including (i) interactions with the surface of the cell membrane, creating "pits" and

54 affecting permeability, (ii) the release silver ions that penetrate the cell and interrupt the

55 replication of DNA, and (iii) the production of ROS.

Both silver salts and nanoparticles are added to CWFs in three different ways, i.e., by

57 painting them onto the filter, dipping the filter in a silver solution, and mixing the silver with

58 clay, sawdust, and water in a powder form. One survey found that $33 \%$ of the factories painted

59 the silver solution onto the CWFs, 56\% dipped the CWFs into the silver solution, and the

60 remaining $11 \%$ mixed the silver in powdered form with clay and sawdust [1]. About $83 \%$ of

61 factories used silver nanoparticles, and 17\% used silver nitrate [1].

62 Previous studies of CWFs showed that increasing the concentration of silver added to the

63 CWFs increased the removal of pathogens [10-12]. The current average amount of silver added

64 to CWFs is about $0.003 \mathrm{mg} \mathrm{Ag} / \mathrm{g}$ ceramic. No study has assessed the possibility of obtaining a

65 higher sorption of silver species by the ceramic material while minimizing desorption. The rate

66 of desorption of silver from CWFs has been determined in field and laboratory studies $[12,13]$,

67 but no studies have been performed to evaluate the influence of the type of clay, accessory

68 minerals, and the concentration of silver added to the ceramic materials.

69 The strength of CWFs also is an important factor because it is related to the durability of

70 the filters during transport and use. CWFs are unreinforced, so the strength of the filters depends

71 largely on the tensile strength of the ceramic material used to make the filter. Recent studies by

72 Plapally et al. [14] indicated that clay mineralogy and the combustible material (e.g., sawdust

73 and rice husks) used in manufacturing CWFs affect the pore distribution and hence the strength

74 of the ceramic materials. In this study, we performed a fracture toughness test on single-edged, 
75 notched, bend specimens from different sections of CWFs that were manufactured under

76 controlled conditions in the laboratory. The roles of process variables, such as the ratio of clay to

77 combustible material, the firing program, and the way the materials are handled during the

78 manufacturing process, are still somewhat uncertain.

The objective of this study was to investigate the influence of local clay materials

80 and the manufacturing process on silver sorption/desorption and the strength characteristics of

81 CWFs. The specific hypothesis to be tested is that the silver sorption capacity and strength

82 properties of CWFs can be predicted based on the distribution of the minerals in the clay used to

83 make the CWFs.

84

85

86

87

88

89

90

91

92

93

94

95

96

97

\section{TESTING PROCEDURES}

Ceramic samples were obtained from CWF factories located in the United States (A), Guatemala (B), Ghana (C), Peru (D), and Nicaragua (E). These samples were representative of a wide variety of clay types and manufacturing methods. None of the CWFs had silver added to them during the manufacturing process.

\subsection{Bulk Mineralogy and Chemistry}

The ceramic samples were pulverized using a porcelain mortar and pestle, and the pulverized material was passed through a 150-micron sieve and placed in the sample cell of a Terra X-ray diffraction and fluorescence unit manufactured by InXitu, Inc. Samples were analyzed for at least 50 exposures to the X-ray. Dominant XRD peaks were compared with standard reference profiles for known minerals using XPowder software (http://www.xpowder.com/). Bulk chemistry data, collected during the same analysis, yielded low-resolution detection of the selected metals. 


\subsection{Porosity}

Porosity is defined as the ratio of the volume of voids $\left(V_{v}\right)$ to the total volume $\left(V_{t}\right)$. Thus, it is a measure of the void space in a material. The ceramic materials were dried at $105^{\circ} \mathrm{C}$ until they reached a constant weight. This weight was recorded as $W_{o}$, and then the ceramic materials were immersed in water for $24 \mathrm{~h}$. Then they were weighed again, and this weight was recorded as $W_{f}$. With the voids still full of water, the ceramic materials were covered in parafilm and placed in a graduated cylinder with a known volume of water, recorded as $V_{o}$. Then, the final volume of water after the addition of the ceramic material was recorded as $V_{f}$. The porosity $(n)$ was determined using the following equation:

$n(\%)=\frac{V_{v}}{V_{t}}=\frac{\left(W_{f}-W_{0}\right)}{\left(V_{f}-V_{0}\right)} \times 100$

\subsection{Sorption/Desorption of Silver Species}

Silver nanoparticles were obtained from Laboratorios Argenol SL in Spain (Collargol 70.37\% silver content). The nanoparticles manufactured by Laboratorios Argenol were synthesized by irradiation techniques and stabilized using casein. This is the most common source of silver nanoparticles used by CWF factories. Ionic silver was obtained in the form of silver nitrate $\left(\mathrm{AgNO}_{3}\right)$ from Sigma-Aldrich ( $>99.999 \%$ purity).

Concentrations of ionic silver were determined using a Thermo-Scientific Orion 9616BNWP ion-Plus Sure-Flow Silver/Sulfide probe. The concentration of silver nanoparticles in solution was obtained using ICP-OES (X series, Thermo Elemental); with this method, we are able to detect the total silver in solution, i.e., the combination of silver nanoparticles and ionic silver. 
The experiments were conducted at similar conditions of ionic strength $(I)$ using 0.00147

$121 I$ of $\left.\mathrm{KNO}_{3}(1.9 \mathrm{mM} \mathrm{KNO})_{3}\right)$ and $0.00147 \mathrm{I}$ of $\mathrm{Ca}\left(\mathrm{NO}_{3}\right)_{2}\left(0.48 \mathrm{mM} \mathrm{Ca}\left(\mathrm{NO}_{3}\right)_{2}\right)$, which represented

122 monovalent and divalent electrolytes, respectively. A dynamic light scattering (DLS) system was

123 used to determine the sizes and distributions of the particles in the different electrolyte solutions

124 that were prepared. Malvern Zetasizer Nanoseries ZS90 was used to determine the zeta potential

125 of the silver nanoparticles at the different water chemistry conditions used in the experiments.

126 The characterization methodologies were described by the authors of previously-published work

$127[7,15]$.

Batch sorption experiments for each silver specie on each of the five CWF materials using

129 either monovalent or divalent electrolyte solutions, were performed by combining the sorbent, 130 the aqueous silver solution, and organic-free, deionized (DI) water in 15-mL polypropylene

131 tubes. The mass of sorbent (ceramic material) used in each isotherm experiment was $5 \mathrm{~g}$ with a

132 total sample volume of $1 \mathrm{~cm}^{3}$. The aqueous silver solutions were prepared at concentrations of 10 $133 \mathrm{~g} / \mathrm{L} \mathrm{Ag}^{+}\left(\mathrm{AgNO}_{3}\right)$ and $4.0 \mathrm{~g} / \mathrm{L} \mathrm{Ag}^{0}$. These concentrations and sorbent masses were used to 134 ensure that $30 \%$ to $90 \%$ of the silver species were sorbed at equilibrium. The aqueous silver 135 solution was mixed with DI water prior to contacting the ceramic materials at different ratios.

136 Tubes containing the diluted silver solution and no ceramic were also included in the experiment 137 and analyzed to determine the losses due to contact with the tubes or caps. No significant losses 138 were measured, and recovery in all tubes was determined to be greater than $98 \%$. The difference 139 between the initial and final (equilibrium) mass of silver in the aqueous phase was considered to 140 be equal to that sorbed by the solid phase.

142 models. The Langmuir adsorption isotherm was used to describe the equilibrium between the 
143 surface and the solution as a reversible chemical equilibrium between species. The surface of the 144 adsorbent was made up of fixed individual sites at which molecules of the adsorbate could be 145 chemically bound. We assumed that the reaction had a fixed free energy change for all sites and 146 that each site was capable of binding, at most, one molecule of adsorbate. This assumes, at most, 147 a monolayer of adsorbate on the adsorbent. (35)

148 To model the Langmuir Isotherm, the data were plotted as $\frac{C_{A}}{q_{A}}$ versus $C_{A}$, which resulted in 149 a straight line with a slope of $\frac{1}{Q_{M}}$ and an intercept of $\frac{1}{b_{A} \cdot Q_{M}}$. Linear regression was used to 150 determine the best fit parameters and the Langmuir regression parameters, $Q_{M}$ and $b_{A}$, where $Q_{M}$ 151 is the maximum adsorbent-phase concentration of sorbate when the surface sites are saturated 152 with sorbate, $\left(\frac{m g \text { sorbate }}{g \text { sorbent }}\right)$, and $b_{A}$ is the Langmuir adsorption constant of the sorbate, $\left(\frac{L}{m g}\right)$. $153 \mid \frac{C_{A}}{q_{A}}=\frac{1}{b_{A} \cdot Q_{M}}+\frac{C_{A}}{Q_{M}}(2)$ The Freundlich adsorption isotherm was used to describe the data for heterogeneous 156 adsorbents, such as activated carbon. Heterogeneous adsorbents often have varying site energies 157 and are best described using the Freundlich isotherm. The Freundlich Sorption Equilibrium 158 Model was derived as an empirical equation. It describes the equilibrium for heterogeneous 159 sorbents and is the most frequently-used isotherm for activated carbon. To model the 160 Freundlich isotherm, the data were plotted as $\log \left(q_{A}\right)$ versus $\log \left(C_{A}\right)$, using an equation that 161 results in a straight line with a slope of $\frac{1}{n}$ and an intercept of $\log (K)$. The term $\frac{1}{n}$ is the

162 Freundlich sorption intensity parameter (unitless). K is the Freundlich sorption

163 capacityparameter, $\left(\frac{m g}{g}\right) \cdot\left(\frac{L}{m g}\right)^{\left(\frac{1}{n}\right)}$. 
164

Desorption experiments were conducted to determine the amount of sorbate (silver species) that was desorbed from the sorbent (ceramic materials). After the sorption experiments, the ceramic materials were dried in an oven at $25{ }^{\circ} \mathrm{C}$ for $24 \mathrm{~h}$. This temperature was chosen to simulate the incubator temperatures for both sorption and desorption agitating and the temperature of the drying process used at the filter manufacturing factories. Then, the ceramics were immersed in a vial that contained a background solution with the same background ions as the sorption experiment. The vials were rotated in a rotating tumbler for $24 \mathrm{~h}$ at $25 \mathrm{rpm}$ at $25^{\circ} \mathrm{C}$. Equilibrium concentrations were measured at the completion of this period. Following this, the ceramic materials were removed from the vials and dried in an oven at $25^{\circ} \mathrm{C}$ for $24 \mathrm{~h}$. This procedure was performed twice for each sample of ceramic material.

\subsection{Strength}

Flexural strength was determined using the three-point bending test (ASTM C1161-02c) that is commonly used in testing high-strength ceramic materials. A band saw was used to cut small beams from pieces of the CWFs, and the tests were performed on these small beams. It was only possible to perform the test on ceramic materials A, B, and E due to the lack of appropriate materials shipped from the other factories. It was not feasible to obtain specimens that had dimensions that were in exact accordance with ASTM specifications. Thus, for this study, the height and length of the beams were 1 and $4.5 \mathrm{~cm}$, respectively. The depth of the beams was established by the wall thickness of the CWFs (which ranged from 1.5 to $2 \mathrm{~cm}$ ), so trimming was done only to obtain the necessary width and length. Therefore, trimming did not influence the top or bottom surfaces of the beam, because any changes in these surfaces could have affected the strength of the beam. Figure 1 shows the three different orientations of the 
187 beams that were cut from the sides of the CWFs. The different orientations were used to 188 investigate possible strength anisotropy in the ceramic material associated with the 189 manufacturing process. Specimens trimmed from the bottom of the CWFs were tested in the z190 direction from the inside out.

The following equations were used to calculate flexural stress $\left(\sigma_{f}\right)$ and flexural strain $\left(\varepsilon_{f}\right)$, 192 respectively,[16]:

193

194 \begin{tabular}{r|r}
$\sigma_{f}=\frac{3 P L}{2 w d^{2}}$ \\
195 & $\varepsilon_{f}=\frac{6 D d}{L^{2}}$
\end{tabular}

where $P$ is the load applied to the beam at midspan, $L$ is the length of the span, $w$ is the width of the beam, $d$ is the depth of the beam, and $D$ is the displacement where $P$ is located. The load was applied at a constant displacement rate of 0.005 in/min using a Karol Warner Model 76 Load Frame with a load cell that had a 50-lb capacity. Displacement was calculated by multiplying the specified strain rate by the elapsed time. Equation 2 was used to determine the strength at the maximum applied load.

\section{RESULTS}

\subsection{Bulk mineralogy and geochemistry}

\section{Mineralogy and Geochemistry via simultaneous XRD/XRF}

Ceramic samples from the United States (A), Guatemala (B), Ghana (C), Peru (D), and Nicaragua (E) were analyzed under the same conditions. The ceramic sample from Nicaragua was exceptional in its high background noise, indicating poor crystallinity, which was possibly due to heavy erosion of the source material or additional milling of the ceramic components prior 
212 to assembling the CWFs. Overlapping mineral contents in the fired ceramic material showed that

213 all of the samples except the Nicaraguan samples, had a quartz-dominated matrix (Table 1).

214 Differing amounts of the smectite group of clays occurred in the samples from the U.S., 215 Guatemala, Peru, and, possibly, Nicaragua. Illite was detected in the samples from Peru and 216 Nicaragua. Samples from Guatemala and Peru contained pyroxene grains, which are common in 217 mafic volcanic rocks. The samples from Peru and Nicaragua contained albitic grains, which are 218 commonly found in weathered volcanic terrains. The samples from Ghana were exceptional in 219 that they were essentially all quartz. Note that the smectite group of clays has expandable 220 interlayer spaces, so the clays can accommodate interlayer water or large cations, according to 221 convention (Figure S1 in supplemental information).

\subsection{Porosity}

224 porosity measured, i.e., 48\%, was for the CWFs made in Ghana, and and the minimum porosity, 225 i.e., 40\%, was measured for the CWFs made in the U.S. Table S1 (supplemental information) 226 shows the porosities that were measured for the ceramic materials used in the experiments. techniques used to determine porosity; we used a water intrusion method instead of the mercury

231 porosimetry that was used in other studies [13]. countries is between $35 \%$ and $44 \%$ [1]. Our results fell near the upper limit of the range. This discrepancy with previous studies could be have been caused by the differences in the analytical

3.3. Properties of the silver nanoparticles

Figure 2 shows the mean size of the nanoparticles as a function of the type of electrolyte 
235 increased up to $500 \mathrm{~nm}$. When sodium was used as background ions, the largest size of the 236 aggregates was only $100 \mathrm{~nm}$. The influence of the background electrolytes on the aggregation

237 kinetics of silver nanoparticles was reported previously by several authors with similar results as

those obtained in this study [7, 15, 17-19]. The aggregation of the nanoparticles could limit the penetration of the particles to pores smaller than the size of the aggregate, thereby reducing the amount of silver taken up by the ceramic material.

The zeta potentials of the silver nanoparticles for $\mathrm{Ca}\left(\mathrm{NO}_{3}\right)_{2}$ and $\mathrm{KNO}_{3}$ water conditions were -23.95 and $-18.55 \mathrm{mV}$, respectively. The results implied that the nanoparticles were more stable with $200 \mathrm{mg} / \mathrm{L} \mathrm{KNO}_{3}$ as the background solution than they were in the solution that contained $\mathrm{Ca}\left(\mathrm{NO}_{3}\right)_{2}$. All of the nanoparticles had negative zeta potentials.

\subsection{Sorption of silver compounds}

\subsubsection{Silver Nanoparticles}

Figure 3 shows isotherm results of the batch silver nanoparticles for all the ceramic materials at the different conditions of water chemistry. The isotherm data fitted both the Langmuir isotherm and the Freundlich isotherm for the sorption of the silver nanoparticles. The best fit was chosen by the $\mathrm{R}^{2}$ values. The Freundlich isotherm provided the best fit for the range of concentrations of silver nanoparticles sorbed by the ceramic materials at all water-chemistry conditions that were tested. However, the $\mathrm{R}^{2}$ values were much higher when potassium nitrate was used, indicating a much better fit than that for calcium nitrate. Table 2 shows the fitting parameters. From the fitting of the experimental results, it could be inferred that there was no limit to the amount silver nanoparticles that can be sorbed by the ceramic materials, but, in reality, we know that such a limit exists; we just could not determine what it was at the experimental conditions used in this study. 


\subsubsection{Ionic Silver}

Figure 4 shows the isotherms for all of the ceramic materials at the different water chemistry conditions that were tested. Both Langmuir and Freundlich models fit the isotherm data for silver ion sorption (data not shown). However, the Freundlich fit produced higher $\mathrm{R}^{2}$ values than the Langmuir fit, so the former was selected as the better fit for the tested range of concentrations of silver ions as sorbed by the ceramic materials in all water-chemistry cases. There is one case for which the Freundlich model did not provide the better fit, i.e., 1, ceramic materials from Guatemala with a background solution of calcium nitrate. However, the $\mathrm{R}^{2}$ values for both isotherm fits were greater than 0.9 , indicating a good fit for both the Freundlich and Langmuir models. Table 2 shows details of the parameters used to obtain the fits of the Freundlich and Langmuir models.

\subsection{Desorption}

\subsubsection{Silver Nanoparticles}

Figure 5(a) shows the average desorption per ceramic material for the two solutions. The highest desorption with $\mathrm{KNO}_{3}$ was for ceramic material from Ghana, which had an average desorption of $0.41 \% \pm 0.3 \%$, and the lowest desorption was for the ceramic material from Guatemala, with an average that was below our detection limit. The highest desorption with $\mathrm{Ca}\left(\mathrm{NO}_{3}\right)_{2}$ occurred in the ceramic material from Ghana, which had an average of $1.92 \% \pm$ $1.02 \%$, and the lowest desorption occurred in the ceramic material from Guatemala, which had an average of $0.12 \% \pm 0.09 \%$. For all the ceramic materials tested, higher desorption values were obtained when $\mathrm{Ca}\left(\mathrm{NO}_{3}\right)_{2}$ was used. This difference could have been caused by the particle size of the aggregated nanoparticles. Large aggregates formed in the calcium solutions may not be effectively trapped in the porous matrix of the ceramic material, so they may be desorbed easily. 
282 These results are relevant to the manufacture of CWFs in the different countries, since the water-

283 chemistry conditions used to prepare the silver solution used to coat the CWFs in each location

284 could differ significantly. Factories that use groundwater, which usually has high concentrations

285 of divalent salts, to produce the nano-suspension of silver nanoparticles will produce CWFs that

286 release more silver nanoparticles to the treated water in comparison with factories that use

287 surface water with its low concentrations of divalent salts.

288

289

290

291

292

293

294

295

296

297

298

299

300

301

302

303

304

\subsubsection{Ionic Silver}

Figure 5(b) shows the total average desorption per ceramic material for the two water quality conditions. The maximum desorption with $\mathrm{KNO}_{3}$ occurred with the ceramic material from Nicaragua, with an average of $44.54 \% \pm 27.57 \%$, and the minimum occurred with the ceramic material from Guatemala, with an average of $6.40 \% \pm 4.18 \%$. The highest desorption with $\mathrm{Ca}\left(\mathrm{NO}_{3}\right)_{2}$ occurred with the ceramic material from Ghana, with an average of $12.06 \% \pm$ $6.30 \%$, and the minimum occurred with the ceramic material from Guatemala, with an average of $5.67 \% \pm 2.73 \%$.

\subsection{Strength}

Figure 6 shows typical stress-strain curves from the sides of three different sources in the inside-out $(+\mathrm{R})$ loading direction. As the figure shows, the stress-strain behavior is almost linear, eventually reaching a brittle failure at strains between about $1 \%$ and $3 \%$. The strengths calculated from the flexural tests are summarized in Figure 7.

Independent of the loading direction, the ceramic material from Nicaragua had the highest flexural strength ( $>500 \mathrm{psi}$ ), and USA sample had the lowest $(<150 \mathrm{psi})$. Ceramic material from Guatemala was slightly weaker than that from Nicaragua. To investigate the possible reasons for the difference in strength, the strengths in the $+\mathrm{R}$ direction were plotted 
305 versus effective porosity in Figure 8. As shown in the figure, the strength increases with an 306 increase in effective porosity, an unexpected behavior. A more porous material should have more 307 void space and thus have higher stresses in the ceramic matrix, resulting in a lower strength. 308 Therefore, the differences in strength are expected to be primarily due to differences in the 309 mineralogy of the clay, which could affect the bonding between particles. However, surface 310 imperfections induced by the manufacturing process may also have an effect. The manufacturing process appears to produce a material that has the same strength on 312 the sides as it does on the bottom. This is shown by comparing the strengths measured from the 313 sides on the inside-out loading condition $(+\mathrm{R})$ with the inside-out bottom strengths $(\mathrm{Z})$. For 314 example, ceramic B showed 423 psi (sides) versus 440 psi (bottom), and sample E showed 528 315 psi (sides) versus 510 psi (bottom). The orientation of the specimens on the sides had some effect on the measured strength, 317 suggesting minimal strength anisotropy. The effect was lowest in ceramic E which had a 318 maximum difference of $10 \mathrm{psi}(2 \%)$ for an average strength of $524 \mathrm{psi}$. The anisotropy was more 319 pronounced in ceramic A, which had differences of 20 psi $(23 \%)$ from the average strength of 320132 psi. Also, the material appears to be the strongest when it is loaded from the outside-in (-R) 321 direction rather than the inside-out $(+\mathrm{R})$ direction. However, this may be more attributable to the 322 curvature of the beam than to anisotropy. The - $\mathrm{R}$ loading direction has a beam that is concave 323 down (Figure 1), which produces more of an arch structure that would tend to result in more 324 compressive stresses than tensile stresses, making the material appear to be stronger.

\section{DISCUSSION}


Quartz and smectite-group clay minerals were present in all of the ceramic materials

studied; chemical differences (not assessed here) in the smectite-group clay fraction may be partially responsible for the different sorption behaviors. Ceramic materials from Guatemala and Peru were able to sorb greater amounts of silver nanoparticles; these ceramic materials contain accessory pyroxene $\left(\mathrm{R}_{2} \mathrm{Si}_{2} \mathrm{O}_{6}\right.$, where $\mathrm{R}$ is an available cation, usually $\mathrm{Mg}^{2+}, \mathrm{Fe}^{2+}, \mathrm{Ca}^{2+}, \mathrm{Al}^{3+}, \mathrm{Fe}^{3+}$, $\mathrm{Ti}^{3+}, \mathrm{Mn}^{3+}, \mathrm{Na}^{+}, \mathrm{K}^{+}$, or $\left.\mathrm{Li}^{+}\right)$, and they contain albitic plagioclase feldspar $\left(\mathrm{NaAlSi}_{3} \mathrm{O}_{8}\right)$ [20], so they may have an overall negative surface charge. This may concentrate protons or available cations on the surfaces of the mineral, localizing a patchy, positive charge distribution that would attract the moderately-negative silver nanoparticles. There are several well-known examples of surface charges existing on the surfaces of silicate minerals in response to $\mathrm{pH}$-dependent ion exchange and sorption processes, particularly when $\mathrm{H}^{+}$and $\mathrm{OH}^{-}$interact with surficial ions [21]. In the cases of pyroxene and albite, the negative charges that are fundamental to their silicate structure are likely controlling sorption behavior. More generally, $\mathrm{H}^{+}$and $\mathrm{OH}^{-}$sorption also has been observed in the case of zeolite minerals [22], especially in albites [23].

Regarding the silver nanoparticles used in this study, both their sizes and charges were similar to those of citrate-capped nanoparticles, which are the nanoparticles that are most commonly used in nanoproducts. In previous studies performed by one of the authors [15], it was shown that casein-capped silver nanoparticles have greater stability the capping agents that have lower molecular weights. It was also found that the dissolution of casein-capped nanoparticles was below $0.5 \%$ of the total mass of silver added, so it was expected that the experimental conditions used in this study would have resulted in a similar dissolution rate.

Ceramic materials from Ghana and the U.S. sorbed the least amount; these two materials have simple mineral profiles, consisting of just quartz and smectite-group clays, respectively. 
351 The Nicaraguan ceramic material presented an intermediate case, i.e., sorption properties were

352 intermediate when compared to the high-sorption Guatemala/Peru group and the low-sorption

353 Ghana/U.S. group. XRD data for the Nicaraguan ceramic material suggest the presence of trace

354 albite and pyroxene a lower overall crystallinity, as observed in high background in the XRD

355 results. When potassium nitrate was used as the background solution, high levels of sorption

356 occurred, the use of calcium nitrate as the background solution resulted in significantly less

357 sorption. The importance of the detection of albitic feldspar and pyroxene in the mineral profiles

358 of the ceramic materials that were tested may be as follows. First, the surfaces of natural mineral

359 grains are not regular; in fact, they are quite heterogeneous, with dissolution and reactivity of

360 surface phases dependent on their fine structures, including step and kink features [24]. Second,

361 feldspars are tectosilicate minerals with a three-dimensional array of linked $\mathrm{SiO}_{4}$ and $\mathrm{AlO}_{4}$

362 tetrahedra, with interstices that can host $\mathrm{K}, \mathrm{Na}, \mathrm{Ca}$, or $\mathrm{Ba}$ in electroneutral arrangements [20].

363 Pyroxenes are inosilicates (i.e., chain silicates) composed of linked $\mathrm{SiO}_{4}$ tetrahedra, each sharing

364 two $\mathrm{O}$ atoms with the neighboring tetrahedron. Available cations link the tetrahedral chains

365 together in pyroxenes, yielding a diverse cation (" $\mathrm{R}$ " in mineral formula above) budget for this

366 mineral, although, typically, it is dominated by Fe and Mg. R-O bonds typically are weaker than

367 Si-O bonds in silicate minerals, and natural specimens cleave along these weaker bond planes

368 (Huang, 1989); the resulting natural mixtures of pyroxene grains may have broken R-O bonds at

369 the edges, which may participate more readily in sorption. Indeed, cation exchange and

370 stoichiometric surface dissolution of pyroxene grains are well supported [25]. Although these

371 silicate minerals comprise only a small fraction of the total material, they may provide reactive

372 surfaces for the ionic and silver nanoparticles in experimental systems. 
When potassium nitrate was used as the background solution, the ceramic material from

374 Guatemala sorbed the most ionic silver (followed by Peru), and the ceramic material from

375 Nicaragua sorbed the least. When calcium nitrate was used as the background solution, the 376 ceramic material from Guatemala sorbed the most ionic silver (followed by Peru), and the 377 ceramic material from Ghana sorbed the least. Ceramic materials from Guatemala and Peru 378 contain silicate mineral components (pyroxene or albite), and we propose that these components 379 contributed to the greater sorption capacity of metal ions, as discussed above. These results 380 indicated that the mineralogy of the ceramic material and the water chemistry of the background 381 solutions are important variables to consider when predicting the sorption of ionic silver by 382 ceramic materials.

Steep slopes in the coefficient (or when $1 / \mathrm{n}$ is close to 1 ) indicated high adsorptive 384 capacity at high equilibrium concentrations, but it diminished rapidly at lower equilibrium 385 concentrations. When the slope is relatively flat (or $1 / \mathrm{n}$ is much less than 1 ), it indicates that the 386 sorption capacity is not influenced significantly by lower equilibrium concentrations [26]. The 387 value of $\mathrm{K}$ can be taken as a relative indicator of the adsorptive capacity, and $1 / \mathrm{n}$ is indicative of 388 the energy or intensity of the reaction [27]. The Freundlich isotherm describes multilayer 389 adsorption, and it is not restricted to the formation of the monolayer, as is the Langmuir 390 isotherm. Similarly, the model that fit the silver nanoparticles' sorption isotherm indicated that

392 silver ions seem to exhibit a very high sorption capacity on the ceramic materials. The maximum 393 saturation threshold was not achieved at the experimental conditions used in this study. It was 394 impractical to attain the high concentration required to achieve the threshold in the case of silver 395 nitrate, and aggregation issues associated with the silver nanoparticles precluded achieving it in 
their case as well. It should be noticed that it was not possible to determine the composition of

397 the silver solution inside the pores of the ceramic materials at the end of the sorption test.

398 Therefore, it is possible that some silver still remained in solution (silver nitrate) or suspended

399 (silver nanoparticles) inside the pores and were not necessarily truly sorbed. The average pore

400 volume of the ceramic material was close to $0.5 \mathrm{~cm}^{3}$, and the mass of silver in the pore space

401 could be up to $5 \mathrm{mg}$ at the highest equilibrium concentration obtained, indicating that less than

$402 \quad 12 \%$ of the total silver was sorbed.

Transport of silver nanoparticles with similar physicochemical characteristics through

404

405

406

407

408

409

410

411

412

413

414

415

416

417 418 ceramic manufactured with industrial grade clay have been previously determine in continuous systems [28].. This study showed that most of the desorption happen during the first 200min of the test. In our batch mode experiments we observed that most of the detachment occurred during the first desorption stage.

The desorption tests of silver compounds from the ceramic materials clearly showed the advantage of the use of silver nanoparticles instead of silver ions as an anti-biofouling agent on CWFs. Silver ions desorbed to an extent that was almost an order of magnitude greater than that of the silver nanoparticles. This fact has two main implications, i.e., (i) large losses of chemicals will occur if silver ions are used and (ii) more rinses will be required for CFWs impregnated with silver ions in order to achieve the U.S. Environmental Protection Agency's standard for silver in drinking water of $0.1 \mathrm{mg} / \mathrm{L} \mathrm{[29].} \mathrm{It} \mathrm{also} \mathrm{should} \mathrm{be} \mathrm{noted} \mathrm{that} \mathrm{the} \mathrm{oral} \mathrm{reference} \mathrm{dose} \mathrm{for} \mathrm{silver} \mathrm{is}$ $0.005 \mathrm{mg} / \mathrm{kg} / \mathrm{day}$, so high concentrations of silver in treated water would exceed this standard, and this is especially of concern when one considers children under the age of five, who comprise one of the most important target populations of this technology. 


\section{CONCLUSIONS}

The composition of clay seems to play an important role in the sorption of silver species. The ceramic materials that contained pyroxenes had better sorption of silver, resulting in enhanced performance relative to the removal of pathogens from the water. Also, this finding could allow local manufacturers of CWFs to improve the performance of their ceramic materials by the addition of clays that are rich in pyroxenes.

The results showed that larger amounts of silver ions can be sorbed than silver nanoparticles. However, the desorption of silver nanoparticles from the ceramic materials was less than that of silver ions. Since it is known that silver is critical to the high performance of the filter and that silver nanoparticles are desorbed to a lesser extent, they can be expected to have a longer service life and to pose lower risks to the environment and human health.

Water chemistry is very important for preparing effective silver solutions during the manufacturing process. Water quality does not matter as much for ionic silver applications, but it is important when silver nanoparticles are used. The nanoparticles did not sorb well with the divalent calcium solution, so excessively hard water may not be appropriate for use in preparing nanoparticle solutions for use in CWFs.

In this study, the factor that had the most significant influence on the strength of CWFs was the region of manufacturing, and this was likely due to differences in the clay mineralogy of the source materials. Potentially, the factor that ranked second relative to its influence on the strength of CWFs was the part of the filter that was tested. The factor that had the least influence on the strength of CWFs was the loading direction. In fact, the highest strengths occurred when the samples were loaded from the outside inward, suggesting that the pressing during the manufacturing process did not induce significant anisotropy in the material. 
444 


\section{REFERENCES}

[1] J. Rayner, Current practices in manufacturing of cermic pot filters for water treatment, in: Water, Engineering and Development Center, Loughborough University, Loughborough, 2009.

[2] O. Choi, K.K. Deng, N.J. Kim, L. Ross, R.Y. Surampalli, Z.Q. Hu, The inhibitory effects of silver nanoparticles, silver ions, and silver chloride colloids on microbial growth, Water Res., 42 (2008) 30663074.

[3] A.J. Kora, J. Arunachalam, Assessment of antibacterial activity of silver nanoparticles on Pseudomonas aeruginosa and its mechanism of action, World J. Microbiol. Biotechnol., 27 (2011) 12091216.

[4] Q.L. Li, S. Mahendra, D.Y. Lyon, L. Brunet, M.V. Liga, D. Li, P.J.J. Alvarez, Antimicrobial nanomaterials for water disinfection and microbial control: Potential applications and implications, Water Res., 42 (2008) 4591-4602.

[5] V. Oyanedel-Craver, Chaper 3 Silver nanoparticlse, Partnership for Appropriate Technology in Heath, Seattle, 2011.

[6] J.P. Ruparelia, A.K. Chatteriee, S.P. Duttagupta, S. Mukherji, Strain specificity in antimicrobial activity of silver and copper nanoparticles, Acta Biomater., 4 (2008) 707-716.

[7] H. Zhang, V. Oyanedel-Craver, Evaluation of the disinfectant performance of silver nanoparticles in different water chemistry conditions, Journal of Environmental Engineering-Asce, 138 (2012) 58-66.

[8] H.J. Park, J.Y. Kim, J. Kim, J.H. Lee, J.S. Hahn, M.B. Gu, J. Yoon, Silver-ion-mediated reactive oxygen species generation affecting bactericidal activity, Water Res., 43 (2009) 1027-1032.

[9] O. Choi, Z. Hu, Size dependent and reactive oxygen species related nanosilver toxicity to nitrifying bacteria, Environmental Science and Technology, 42 (2008) 4583-4588.

[10] A.R. Bielefeldt, K. Kowalski, R.S. Summers, Bacterial treatment effectiveness of point-of-use ceramic water filters, Water Res., 42 (2009) 927-933.

[11] A.R. Bielefeldt, K. Kowalski, C. Schilling, S. Schreier, A. Kohler, R. Scott Summers, Removal of virus to protozoan sized particles in point-of-use ceramic water filters, Water Res., 44 (2010) 1482-1488. [12] E.N. Kallman, V.A. Oyanedel-Craver, J.A. Smith, Ceramic Filters Impregnated with Silver Nanoparticles for Point-of-Use Water Treatment in Rural Guatemala, Journal of Environmental Engineering-Asce, 137 (2011) 407-415.

[13] V.A. Oyanedel-Craver, J.A. Smith, Sustainable colloidal-silver-impregnated ceramic filter for pointof-use water treatment, Environ. Sci. Technol., 42 (2008) 927-933.

[14] A.K. Plappally, I. Yakub, L.C. Brown, W.O. Soboyejo, A.B.O. Soboyejo, Physical Properties of Porous Clay Ceramic-Ware, Journal of Engineering Materials and Technology, 133 (2011) 031004. [15] H. Zhang, J.A. Smith, V. Oyanedel-Craver, The effect of natural water conditions on the antibacterial effectiveness and stability of silver nanoparticles capped with different polymers, Water Res., 46 (2012) 691-699.

[16] ASTM, ASTM C1161-02c, Standard Test Method for Flexural Strenght at Ambient Tempertaure, in, ASTM International, West Conshohocken, PA, 2008.

[17] E.M. Hotze, T. Phenrat, G.V. Lowry, Nanoparticle Aggregation: Challenges to Understanding Transport and Reactivity in the Environment, Journal of Environmental Quality, 39 (2010) 1909-1924. [18] X.A. Li, J.J. Lenhart, H.W. Walker, Dissolution-Accompanied Aggregation Kinetics of Silver Nanoparticles, Langmuir, 26 (2010) 16690-16698.

[19] X. Li, J.J. Lenhart, H.W. Walker, Dissolution-accompanied aggregation kinetics of silver nanoparticles, Langmuir : the ACS journal of surfaces and colloids, 26 (2010) 16690-16698. [20] P.M. Huang, Feldspars, Olivines, Pyroxenes, and Amphiboles, Soil Science Society of America, Madison, Wisconsin, USA, 1989.

[21] H.C. Helgeson, W.M. Murphy, P. Aagaard, Thermodynamic and kinetic constraints on reaction rates among minerals and aqueous solutions. II. Rate constants, effective surface area, and the hydrolysis of feldspar, Geochim. Cosmochim. Acta, 48 (1984) 2405-2432. 
[22] N. Lihareva, L. Dimova, O. Petrov, Y. Tzvetanova, Ag+ sorption on natural and Na-exchanged

498 [23] R. Wollast, L. Chou, Surface reactions during the early stages of weathering of albite, Geochim.

499 Cosmochim. Acta, 56 (1992) 3113-3121.

500 [24] W. Stumm, Reactivity at the mineral-water interface: Dissolution and inhibition, Colloids and

501 Surfaces a-Physicochemical and Engineering Aspects, 120 (1997) 143-166.

502 [25] W.M. Murphy, H.C. Helgeson, Thermodynamic and kinetic constraints on reaction rates among

503 minerals and aqueous solutions; IV, Retrieval of rate constants and activation parameters for the

504 hydrolysis of pyroxene, wollastonite, olivine, andalusite, quartz, and nepheline, Am. J. Sci., 289 (1989)

505 17-101.

506 [26] S. Faust, A. Osman, Adsorption process for water treatment, Butterworth Publisher, 1987.

507 [27] F. Slejko, Adsorption Technology, Marcek Dekker, Inc., 1985.

508 [28] D. Ren, J.A. Smith, Retention and transport of silver nanoparticles in a ceramic porous medium used

509 for point-of-use water treatment, Environ. Sci. Technol., 47 (2013) 3825-3832.

510 [29] USEPA, http://water.epa.gov/drink/contaminants/index.cfm, in, 2011. 

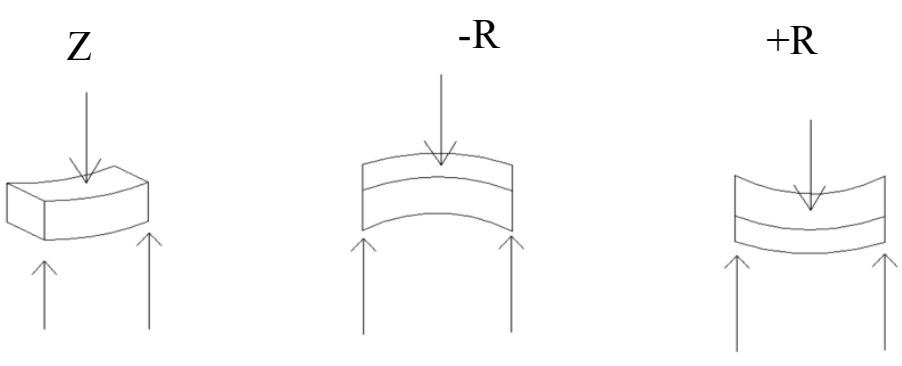

521 


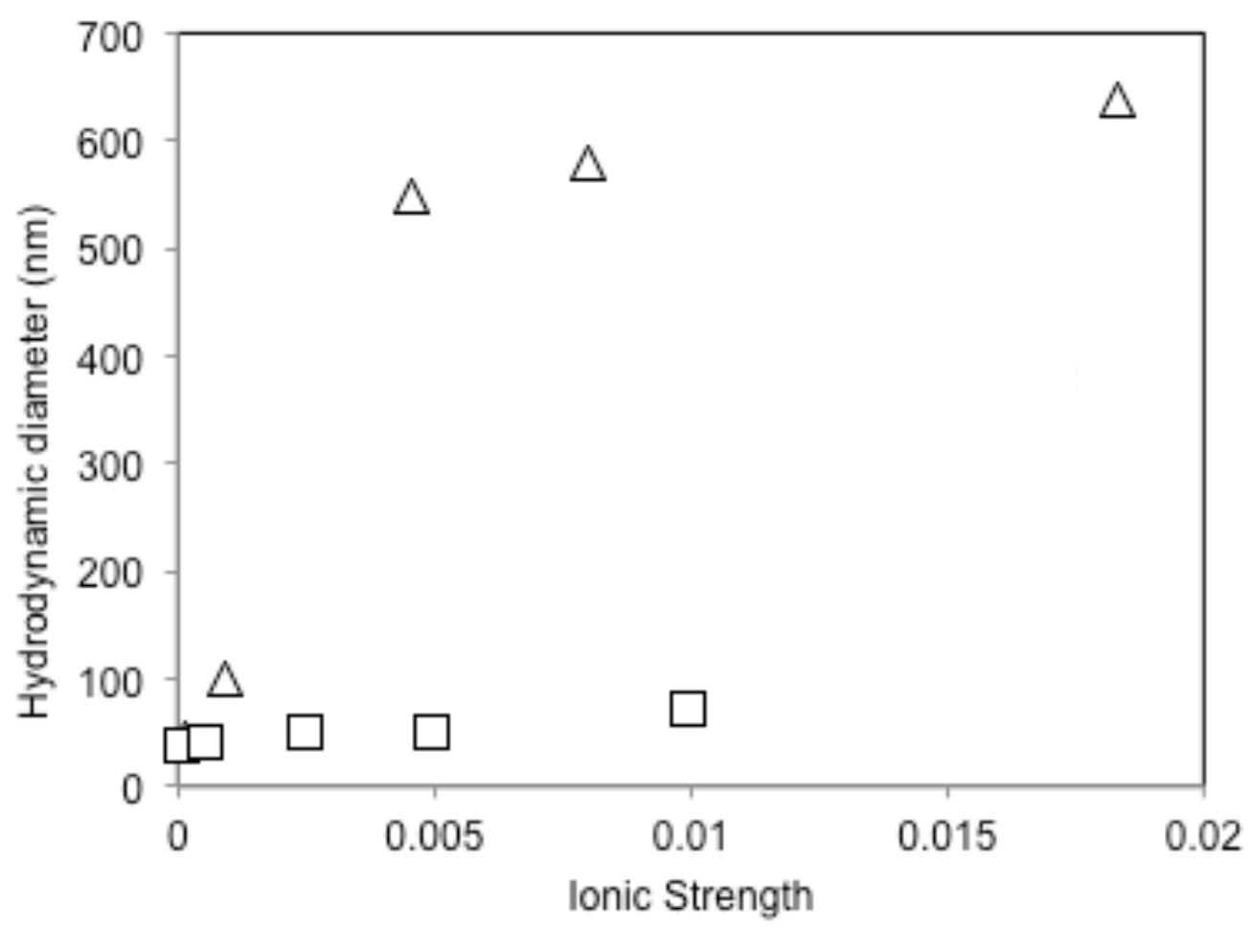

525

Figure 2. Evolution of the hydrodynamic diameter at increasing ionic strenght of 

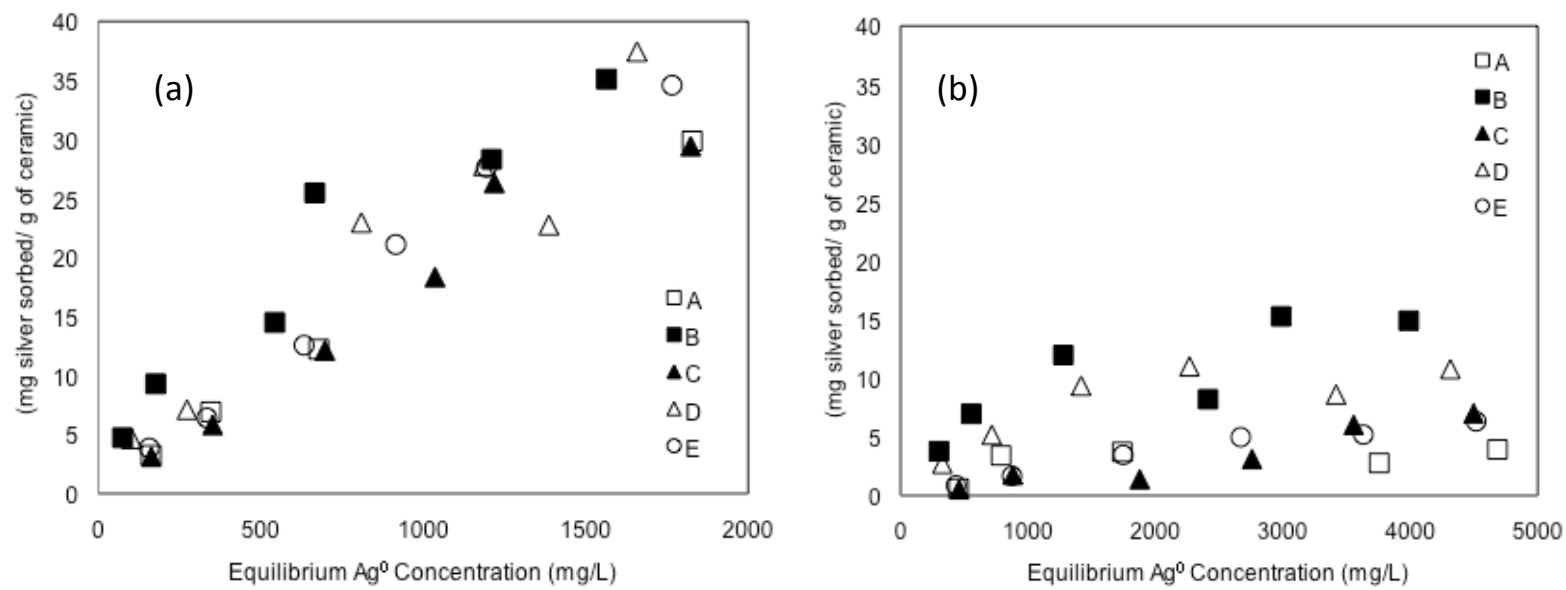

530 Figure 3. Silver nanoparticle sorption isotherms for ceramics (A) USA, (B) Guatemala, (C)

531 Ghana, (D) Peru and (E) Nicaragua at the water chemistry conditions (a) $\mathrm{KNO}_{3}$, and (b) 

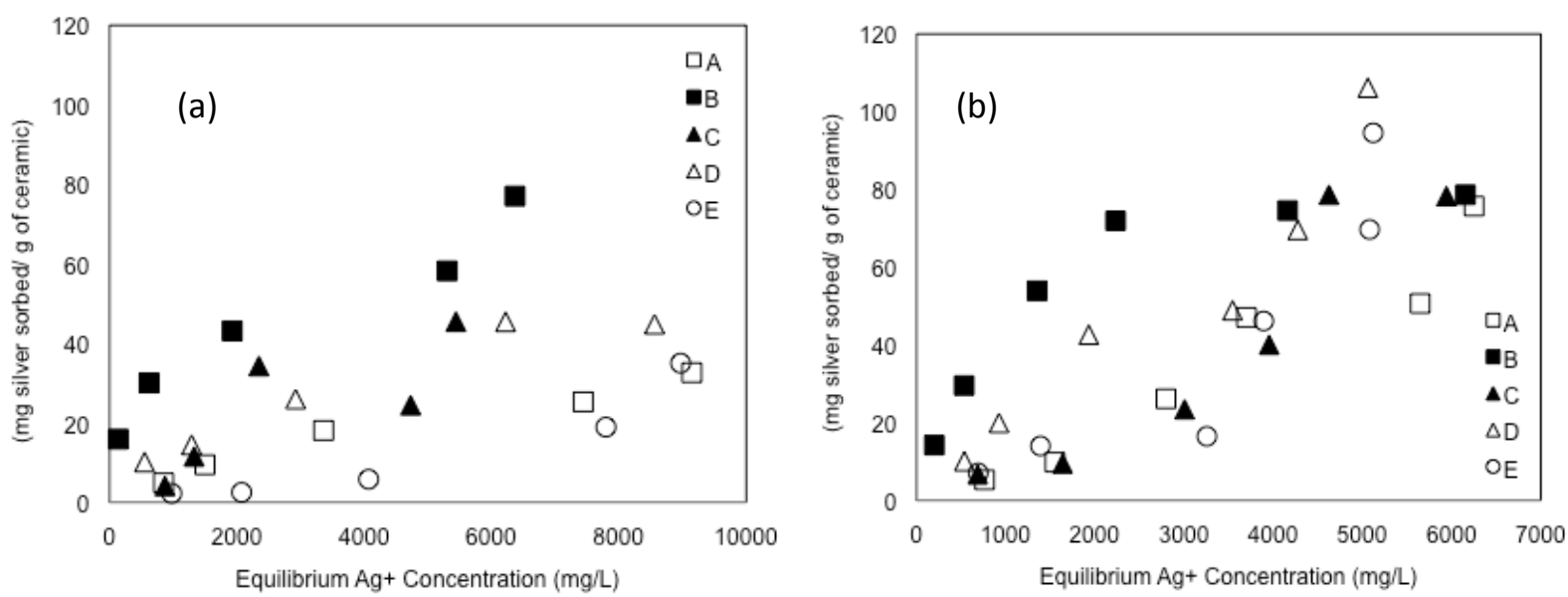

Figure 4. Silver ions sorption isotherms for ceramics (A) USA, (B) Guatemala, (C) Ghana, (D) Peru and (E) Nicaragua at the water chemistry conditions (a) $\mathrm{KNO}_{3}$, and (b) $\mathrm{Ca}\left(\mathrm{NO}_{3}\right)_{2}$ 

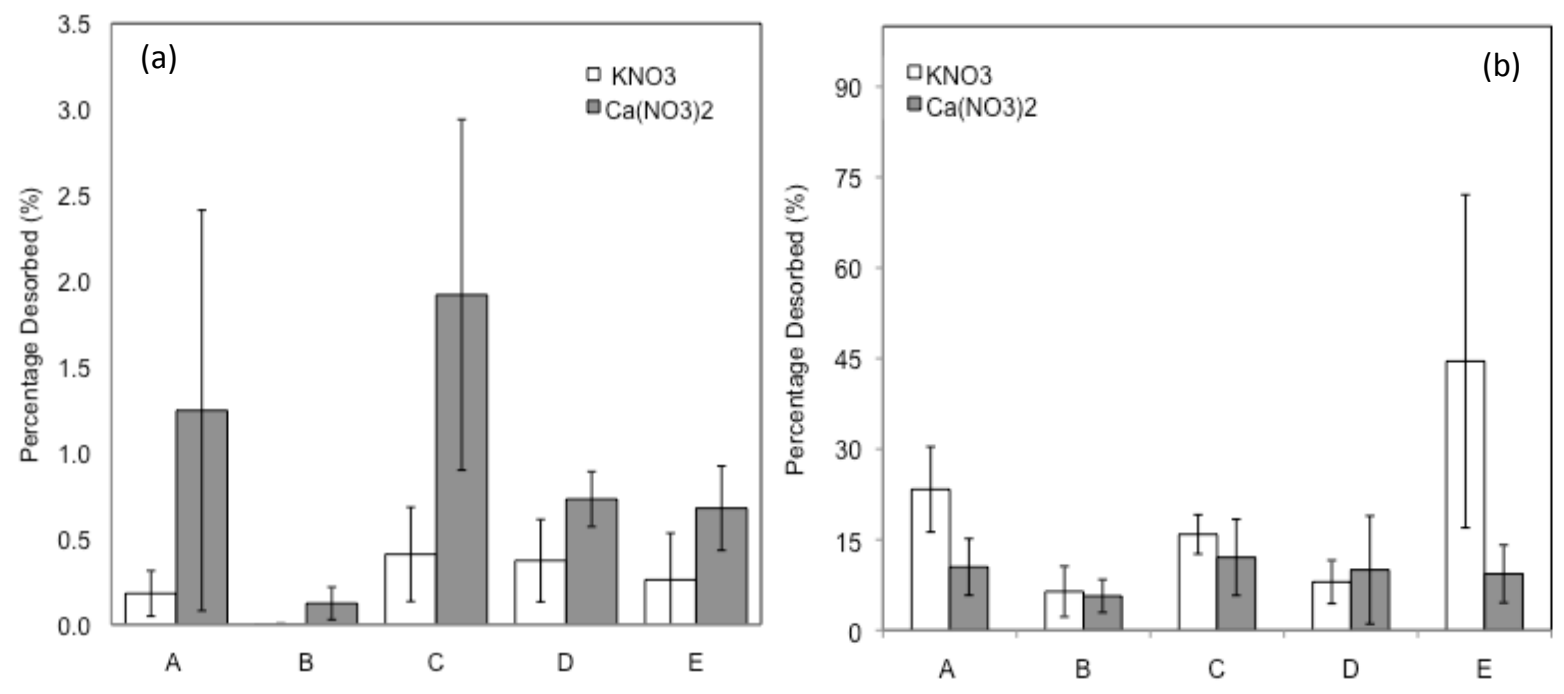

540

541

542

543

544

545

Figure 5. (a) Percentage of silver nanoparticle desorption and (b) percentage of ionic silver desorption at different water chemistry conditions for ceramics from (A) USA, (B)

Guatemala, (C) Ghana, (D) Peru and (E) Nicaragua 


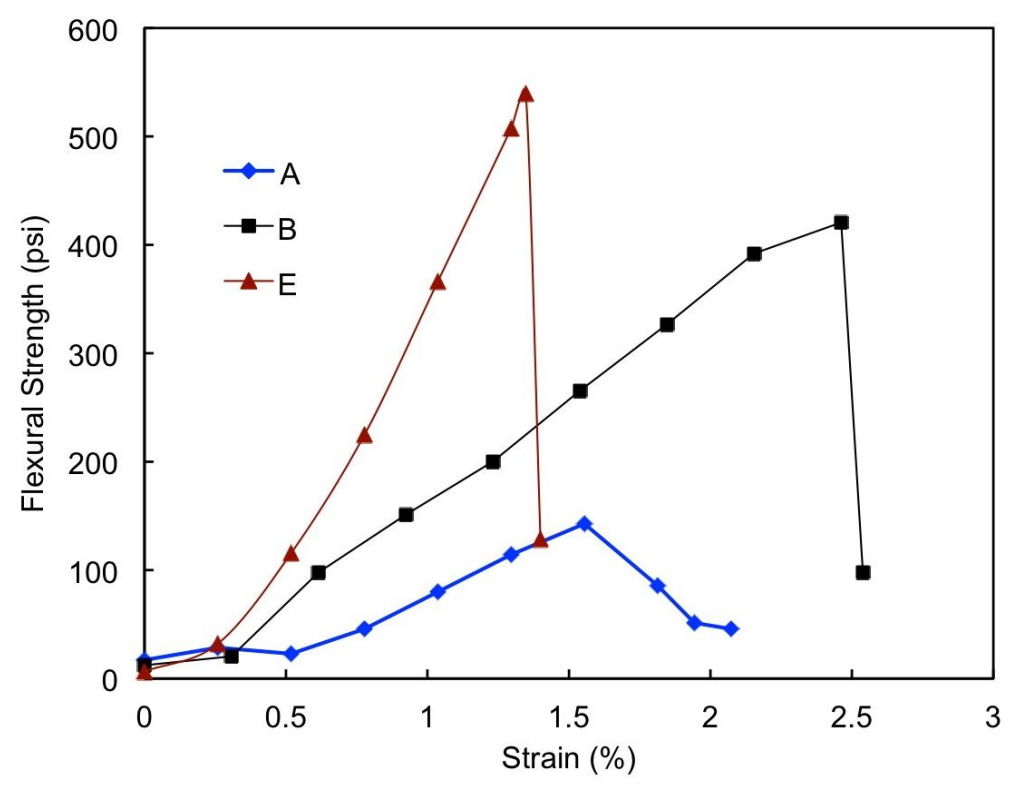

Figure 6. Typical flexural test results from three CWF sources under the same loading orientation (+R direction). (A) USA, (B) Guatemala, and (E) Nicaragua 


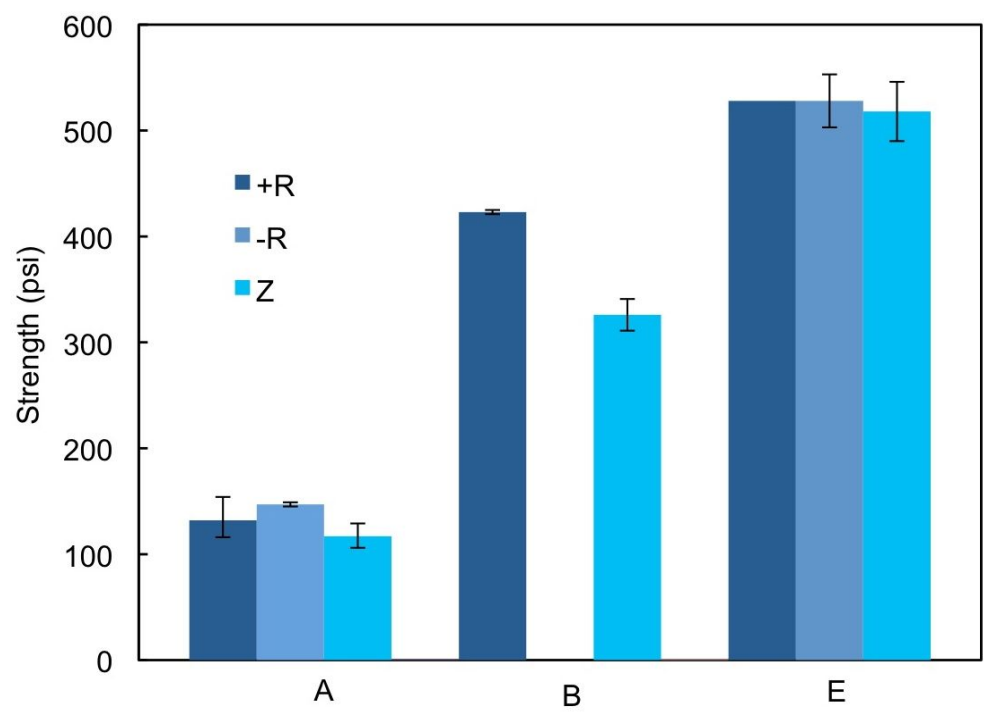

554

555

556

557

558

559
Figure 7. Summary of flexural strength test results for three CWF sources. The error bars shown represent the minimum and maximum measured strength. (A) USA, (B) Guatemala, and (E) Nicaragua. 


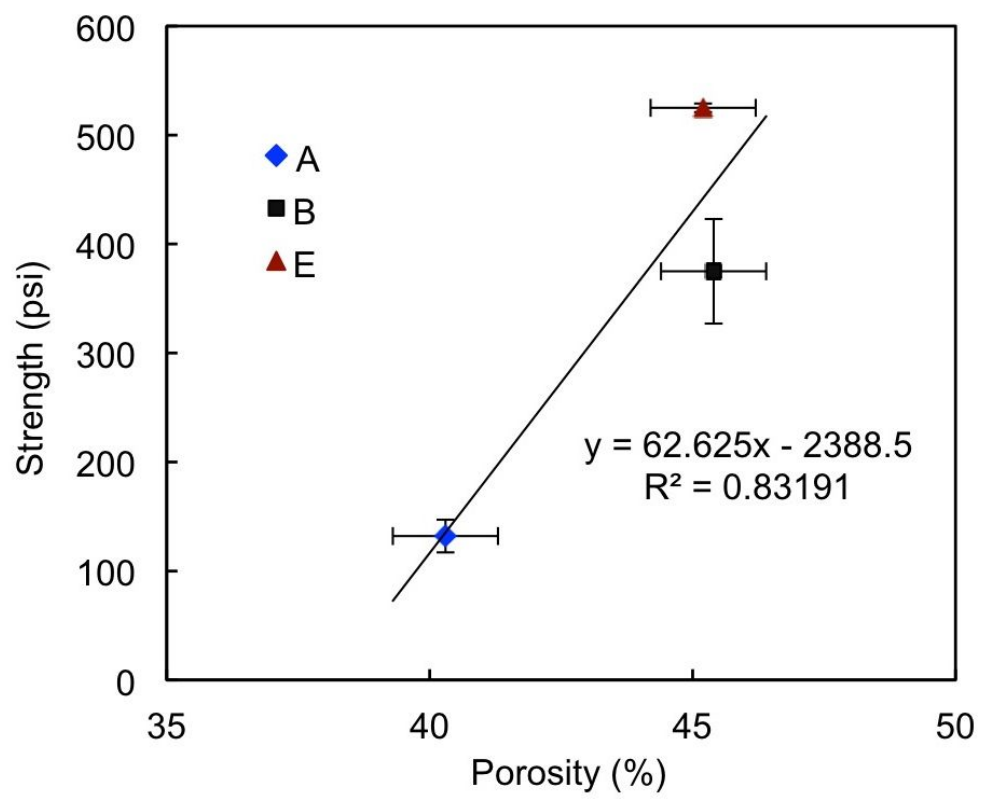

Figure 8. Correlation between flexural strength and porosity for the $+R$ loading direction for three $\mathrm{CWF}$ sources. The error bars shown represent the minimum and maximum values. (A) USA, (B) Guatemala, and (E) Nicaragua 
Tables

601

Table 1. Summary table of bulk powder XRD and XRF results. All samples were analyzed under identical conditions.

\begin{tabular}{|c|c|c|c|}
\hline Sample provenance & Bulk XRD & Bulk XRF & Additional notes \\
\hline USA & $\begin{array}{l}\text { Quartz, minor } 16 \AA \text { smectite } \\
\text { group clay }\end{array}$ & $\mathrm{K}, \mathrm{Ti}, \mathrm{Cr}$ & $\begin{array}{l}\text { Illite suggested by minor peak at } \\
3.49 \AA \text { (small peak area, irregular } \\
\text { boundary). }\end{array}$ \\
\hline Guatemala & $\begin{array}{l}\text { Quartz, pyroxene (likely } \\
\text { derived from arc volcanics), } \\
\text { minor } 16 \AA \text { smectite group clay }\end{array}$ & $\begin{array}{l}\mathrm{Ca}, \mathrm{Ti}, \mathrm{Mn}, \mathrm{Fe}, \\
\mathrm{Eu}\end{array}$ & $\begin{array}{l}\text { Abundant volcanic ash from } \\
\text { nearby convergent margin } \\
\text { magmatism along the western } \\
\text { boundary of Central and South } \\
\text { America is likely the precursor to } \\
\text { clay units utilized in this ceramic. }\end{array}$ \\
\hline Ghana & $\begin{array}{l}\text { Essentially all quartz, minor } \\
16 \AA \text { smectite group clay }\end{array}$ & $\mathrm{K}, \mathrm{Ti}, \mathrm{Cr}, \mathrm{Fe}$ & $\begin{array}{l}\text { Geologic units of this region of } \\
\text { Northern Ghana include shales and } \\
\text { sandstones of the Voltaian Group } \\
\text { (Anani, 1999), leading to a quartz- } \\
\text { rich source with clays derived } \\
\text { likely from sedimentary } \\
\text { formations. }\end{array}$ \\
\hline Peru & $\begin{array}{l}\text { Quartz, albite, possible illite, } \\
\text { and minor } 16 \AA \text { smectite group } \\
\text { clay }\end{array}$ & $\begin{array}{l}\mathrm{K}, \mathrm{Ca}, \mathrm{Ti}, \mathrm{Fe}, \\
\text { possible } \mathrm{Sn}\end{array}$ & $\begin{array}{l}\text { This clay source is also likely } \\
\text { derived from volcanic ash. }\end{array}$ \\
\hline Nicaragua & $\begin{array}{l}\text { Quartz, albite, illite-group clay, } \\
\text { minor } 16 \AA \text { smectite group clay, } \\
\text { and pyroxene. }\end{array}$ & $\begin{array}{l}\mathrm{Ca}, \mathrm{Ti}, \mathrm{Cr}, \mathrm{Mo} \\
\text { Fe, Mn, Eu, Pm }\end{array}$ & $\begin{array}{l}\text { High background suggests poorly } \\
\text { crystalline matrix. This clay source } \\
\text { is likely derived from volcanic ash. }\end{array}$ \\
\hline
\end{tabular}

602

603

604

605

606

607

608

609

610

611 
612

613

Table 2. Fitting parameters for all the experiments

\begin{tabular}{|c|c|c|c|c|c|c|c|}
\hline & \multirow{3}{*}{ Sample } & \multirow{2}{*}{\multicolumn{3}{|c|}{ Langmuir }} & & & \\
\hline & & & & & \multicolumn{3}{|c|}{ Freundlich } \\
\hline & & $Q_{M}$ & $b_{A}$ & $\mathrm{R}^{2}$ & $\mathrm{n}$ & $K$ & $R^{2}$ \\
\hline \multirow[b]{5}{*}{$\mathrm{Ag}^{0}-\mathrm{Ca}\left(\mathrm{NO}_{3}\right)_{2}$} & A & 13.8 & 0.4 & 0.65 & 1.791 & 0.039 & 0.78 \\
\hline & B & 65.0 & 0.3 & 0.74 & 2.136 & 0.313 & 0.79 \\
\hline & C & 4.9 & 0.8 & 0.47 & 0.966 & 0.001 & 0.87 \\
\hline & D & 60.7 & 0.2 & 0.92 & 1.955 & 0.170 & 0.83 \\
\hline & $\mathbf{F}$ & 10.0 & 1.8 & 0.81 & 1.165 & 0.005 & 0.98 \\
\hline \multirow[b]{5}{*}{$\mathrm{Ag}^{0}-\mathrm{KNO}_{3}$} & A & 63.7 & 6.6 & 0.49 & 1.059 & 0.027 & 0.99 \\
\hline & B & 90.0 & 0.6 & 0.82 & 1.548 & 0.305 & 0.97 \\
\hline & C & 33.3 & 23.3 & 0.45 & 1.010 & 0.019 & 0.99 \\
\hline & D & 62.2 & 1.0 & 0.57 & 1.346 & 0.135 & 0.96 \\
\hline & $F$ & 38.9 & 14.5 & 0.45 & 1.035 & 0.027 & 0.99 \\
\hline \multirow[b]{5}{*}{$\mathrm{Ag}^{+}-\mathrm{Ca}\left(\mathrm{NO}_{3}\right)_{2}$} & A & 74.8 & 1.7 & 0.56 & 0.785 & 0.001 & 0.97 \\
\hline & B & 570.6 & 0.2 & 0.99 & 1.959 & 1.131 & 0.93 \\
\hline & C & 39.1 & 0.2 & 0.43 & 0.799 & 0.001 & 0.91 \\
\hline & D & 102.8 & 5.0 & 0.41 & 1.075 & 0.032 & 0.96 \\
\hline & $\mathbf{F}$ & 40.1 & 0.3 & 0.32 & 0.863 & 0.003 & 0.84 \\
\hline \multirow[b]{5}{*}{$\mathrm{Ag}^{+}-\mathrm{KNO}_{3}$} & A & 4.4 & 0.6 & 0.90 & 1.327 & 0.034 & 0.97 \\
\hline & B & 11.4 & 0.8 & 0.94 & 2.606 & 2.416 & 0.98 \\
\hline & C & 36.8 & 0.8 & 0.45 & 0.918 & 0.004 & 0.78 \\
\hline & D & 143.1 & 0.5 & 0.94 & 1.688 & 0.228 & 0.98 \\
\hline & $F$ & 12.0 & 0.2 & 0.42 & 0.800 & 0.000 & 0.88 \\
\hline
\end{tabular}

